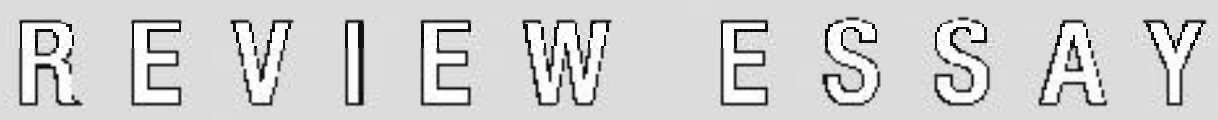
af Michael Hviid Jacobsen

\title{
Den mosaikagtige og moralske Bauman - mellem mikro og makro
}

Bauman, Zygmunt (2004a): Identity - Conversations with Benedetto Vecchi. Cambridge: Polity Press (104 sider).

Bauman, Zygmunt (2004b): Europe - An Unfinished Adventure. Cambridge: Polity Press (152 sider).

\section{Den sociologiske fantasi i \\ forfatterskabets mosaikagtige fase}

Zygmunt Baumans skrivemaskine må efterhånden været godt og grundigt slidt. I løbet af 2004 udkom således hans bøger nr. 26 og 27, såfremt vi i denne optælling kun inkluderer hans engelsksprogede udgivelser. Heraf er intet mindre end de seneste otte udkommet siden årtusindeskiftet. Produktiviteten har, som kritikere gentagne gange har påpeget, til tider smittet af på kvaliteten. Dette har jeg også selv har bemærket i flere anmeldelser af hans nyere arbejde, hvor jeg har fremført, at reproduktion og gentagelse til tider overskygger nyskabelse og originalitet. Dog er der stadig meget substans at hente i Baumans tidsdiagnostiske arbejder, der giver stof til eftertanke for os som sociologer, men måske mest af alt som mennesker. Ikke blot i substantiel forstand er der i de senere år sket ændringer i Baumans forfatterskab, men også stilistisk. Den essayistiske skrivestil har altid været et kendetegn for Bauman, men særligt $i$ hans såkaldt "mosaikagtige fase" i de seneste år (jf. Jacobsen 2004:21-22), hvor han tager livtag med en mangfoldighed af forskelligartede temaer, har den essayistiske skrivestil været et udpræget kendetegn for hans arbejde. Bauman er nu mere eller mindre ophørt med at skrive "sociologisk teori" og har i stedet gradvist bevæget sig ind på det område, der med Ulrich Beck og kollegers betegnelse 
kan karakteriseres som "sociologisk samtidsdiagnose" (jf. Carleheden 2006). På denne måde afspejler hans arbejde også en generel tendens i dele af nutidens sociologi, hvor de store anerkendte samfundstænkere, som Giddens, Beck, Bourdieu og Habermas, snarere skriver eller har skrevet forholdsvis sporadiske eller generelle samtidsdiagnoser end foretager systematiske empirisk-baserede analyser eller udarbejder store teoretiske systemer, som de tidligere ellers var kendt for.

Det er derfor måske ikke så overraskende, at de seneste to bøger fra Baumans hånd, Identity - Conversations with Benedetto Vecchi og Europe - An Unfinished Adventure, mest af alt egentlig kvalificerer som to lange samtidsdiagnostiske essays. Begge bøger er udgivet i Polity Press' lille "sorte serie" om Themes for the 21st Century, hvori Bauman tidligere har bidraget med bøger om globalisering og fællesskab. Deres form- og udgivelsesmæssige ligheder til trods omhandler Identity og Europe dog som udgangspunkt to vidt forskellige temaer, der normalt befinder sig på hver sit niveau i de fleste samfundsanalyser - nemlig mikroanalysen af identitet i samtidens flydende modernitet (i modsætning til fortidens faste modernitet) i Identity, og det europæiske fællesskab og dets historiske erfaringer som værdigrundlag for en humanistisk global verdensorden i Europe. Dog skal den pointe allerede her trækkes frem, som jeg vil søge at underbygge yderligere i dette review-essays afslutning, at det er kendetegnende for Bauman, at han aldrig adskiller tingene eller kunstigt opdeler verden, hverken analytisk eller praktisk, men at hans sociologiske fantasi omspænder og indfanger såvel den individuelle oplevelse som de strukturelle vilkår, der omkranser og ofte ligefrem er bestemmende for denne. Ophavsmanden til betegnelsen "den sociologiske fantasi", Charles Wright Mills, bemærkede som bekendt om denne bevidsthedsindstilling eller kognitive evne, at den "sætter sin ejermand i stand til at forstå den større historiske scene i lyset af, hvad den betyder for forskellige individers indre liv og ydre livsforløb", og videre, at "den sociologiske fantasi sætter os i stand til at forstå historien og biografien og deres indbyrdes relationer i samfundet. Det er dens opgave og dens løfte" (Mills 1959/2002:17-18). Baumans to nyeste bøger bærer tydelige vidnesbyrd om hans indfrielse af den sociologiske fantasis løfte. Men for ikke at konkludere for tidligt i dette review-essay, så lad mig i det nedenstående først kort gennemgå hovedpointerne fra de to bøger, hvorefter jeg afslutningsvis vil forsøge at samle trådene fra bøgerne i en samlet vurdering.

\section{Mikroanalysen i Identity - Conversations with Benedetto Vecchi}

Overordnet set kan denne bog betragtes som et forsøg på at samle op på alle de tidligere ansatser til en identitetsteori, som Bauman har tilvejebragt gennem en række af hans udgivelser det seneste årti. Jeg har tidligere bemærket, at Bauman aldrig fremstiller en egentlig sammenhængende identitetsteori (Jacobsen 2004:237), men det er der altså nu tilsyneladende rådet bod på med 
Identity - Conversations with Benedetto Vecchi. Som undertitlen angiver, er der tale om en form for interview-bog, der i dialogisk form tager fat på identitetsproblematikken i en mangfoldighed af forskellige afskygninger lige fra personlig identitet til national identitet, "ægte" kontra "falsk" identitet, indre-styret over for andre-styret identitet, producent- versus forbrugeridentitet, fællesskab over for individualitet, fortidens forudbestemte identitet versus nutidens flydende og fragmenterede identitet osv. Karakteristisk for Bauman behandles identitetstemaet således ikke $\mathrm{i}$ isolation, men i relation til mange af hans traditionelle interesseområder såsom ambivalens, magt, marginalisering, frygt, moral, stratifikation og frihed. Bogen indledes med et kort, men informationsmættet forord af den italienske journalist og samtalepartner Benedetto Vecchi, hvori konteksten for interviewene skildres, og hvor nogle få biografiske nedslag i Baumans liv og levned foretages. Vecchi indfanger ganske godt den ovenfor postulerede mikro-makro-sammenkædning i Baumans forfatterskab i forhold til identitets-problematikken ved at konstatere om identitet, at det vigtige består $i$ at "at re-konstruere overgangen fra den individuelle dimension, som identitet altid besidder, til dens kodificering som en social konvention" (Bauman 2004a:8). Det vil sige, at vi skal forsøge at forstå, hvordan den indre og dybt personlige følelse af (selv)identitet samtidig i vid udstrækning er formet og indpodet udefra af strukturelle vilkår, og at identitetsvalg ikke blot er en individuel, men også en social proces, som mange klassiske sociologer siden tidernes morgen har betonet. Det er netop denne evindelige dobbelthed eller dialektik i identiteten, om man vil, som Bauman forsøger at illustrere og indfange i denne bog.

Ved at trække på sine egne personlige erfaringer påbegynder Bauman bogen med at illustrere vanskelighederne ved enten at vælge mellem eller være tvunget eller forudbestemt til en bestemt identitet. Begge oplevelser er præget af identitetsspændinger og ambivalens, som da han blev bedt om at vælge nationalmelodi ved overdragelsesceremonien, da han for nylig skulle tildeles et æresdoktorat i Tjekkiet. Hvad skulle han vælge, hvad var hans identitet? Var han polak, fordi han i sin tid var født i Polen, der dog senere fratog ham statsborgerskabet, eller skulle han vælge den engelske nationalhymne, fordi han havde levet der i eksil igennem næsten halvdelen af sit voksenliv og nu var blevet naturaliseret? Disse dybtliggende genvordigheder medførte i sidste instans, at han valgte den europæiske nationalmelodi, der bygger på Beethovens musikalske bearbejdning af Schillers An die Freude, hvilket stemmer meget godt overens med det perspektiv, han fremlægger i dette review-essays anden omtalte bog Europe, hvor netop den universalistiske og inklusive betoning af, at alle Menschen werden Brüder, står centralt i hans argumentation. I Identity er det derimod primært spændingen mellem valgfrihed og tvang, autonomi og heteronomi, der optager ham, i forhold til spørgsmålet: Hvordan kan jeg være en anden, end den jeg er? Eller alternativt som i Søren Kierkegaards store identitetsspørgsmål, i Johannes Møllehaves udlægning, der omhandlede: Hvordan kan 
jeg blive den, jeg skal være? Dette er ikke bare et problem for nutidens mennesker, men det er ifølge Baumans bog noget, der er er særligt kendetegnende for de mennesker, der lever i samtidens flydende modernitet, hvor vi - eller i det mindste nogle af os - frit kan vælge identitet efter behov og behag. Andre, mindre heldige, er derimod overladt til at acceptere de identiteter, de tildeles eller påtvinges.

Bogen tilkendegiver også, at identitetsbetegnelsen i takt med menneskers stigende valgfrihed de seneste år er blevet et af sociologiens nye honnørord, hvilket Bauman bemærker på følgende vis:

For blot et par årtier siden var "identitet" slet ikke noget, der optog vores tanker, og det var udelukkende et objekt for filosofisk meditation. I dag er "identitet" derimod det hotteste samtaleemne, et brændende punkt på alles læber eller i deres bevidsthed (Bauman 2004a:17).

Hvor det op igennem 1970'ernes og 1980'ernes sociologi var helt andre begreber og fænomener, der i overvejende grad optog samfundstænkere, så har identitetsbegrebet siden slutningen af 1980'erne holdt sit indtog og sammen med en række andre subjekt-orienterede og individualistiske termer overtaget den mere strukturelle eller systemiske betoning, som kendetegnede tidligere tiders sociologi. Baumans bog er selv et udtryk herfor, selvom han dog netop forsøger at vise, at identitet ikke blot er et individuelt eller solipsistisk projekt afkoblet fra andre sociale eller strukturelle forhold. Således skriver Bauman om dette, og hermed indirekte også om koblingen mellem mikro og makro:

Identitetens kerne - svaret på spørgsmålet "Hvem er jeg?" og endnu mere vigtigt den vedvarende troværdighed af et hvilket som helst svar herpå - kan ikke skabes uden henvisning til de bånd, der kobler selvet til andre mennesker og antagelsen om, at disse bånd er pålidelige og stabile over tid (Bauman 2004a:68).

Det er kun igennem relationen til andre og til "samfundet" $i$ almindelighed, at identitet kan opretholdes, valideres og i sidste instans opnå den pålidelighed og stabilitet, som de fleste identiteter selv i en flydende samtid har brug for. Problemet, eller paradokset, opstår, når den soliditet og stabilitet, som efterstræbes, vedvarende undermineres af det hastighed, hvormed sociale relationer og menneskelige forhold indgås og brydes, som Bauman også viste i sin bog fra 2003 med titlen Flydende kærlighed. Denne dystre diagnose videreføres med ufortrøden styrke i Identity.

Identitetsbegrebet hos Bauman hænger derfor også uløseligt sammen med hans generelle modernitetsopfattelse, der omhandler transformationen fra en fast til en flydende modernitet, hvilket indvarsles af bogen Flydende modernitet 
fra 2000. Modernitetens transformation og metamorfose påvirker på gennemgribende vis både de mest intime og de mest distancerede aspekter ved menneskers tilværelse, og identiteten går således ingenlunde ram forbi. Moderniteten gjorde nemlig enhver førmoderne og fastforankret identitet - religiøs, social, seksuel, kulturel, professionel - usikker og uholdbar. Intet kunne tages for givet eller forventes at vare ved. Med den moderne verdens fremmarch blev identitet pludselig andet og mere end blot en forudgivet og prædetermineret bestemmelse af mennesket. Det blev en opgave og et valg, og dermed blev det også noget, man kunne arbejde på, ændre, modificere, revidere etc.:

At stille spørgsmålet "hvem er jeg" giver kun mening, hvis du tror, du kan være en anden, end den du er; kun hvis du har et valg, og kun hvis det afhænger af, hvad du vælger; kun hvis det er nødvendigt at gøre noget, for at valget skal virke "rigtigt" og varigt (Bauman 2004a:19).

Moderniteten frisatte identiteten fra fortidens bånd og gjorde det dermed muligt for mennesker at konstruere deres egne identiteter. Dette har siden været årsag til såvel frihed som frustration. Thomas Ziehes "kulturelle frisættelse" var således samtidig også en identitetsmæssig frisættelse:

Identiteterne blev givet fri, og det er nu op til individuelle mænd og kvinder at forsøge at fange dem i flugt ved hjælp af deres egne redskaber. Længslen efter identitet stammer fra ønsket om sikkerhed (Bauman 2004a:29).

Denne søgen efter sikkerhed, tryghed og vished kulminerer i dag på makroplanet i det, Bauman i Europe betegner som "sikkerhedsstaten", og på mikroplanet viser den sig i form af vedvarende - til tider kreative, til andre tider ubehjælpelige - forsøg på konstant at konstruere nye og afvikle forældede identiteter, så man på den ene side ikke holdes fanget i én identitet alt for længe, samtidig med at ens liv på den anden side heller ikke bliver for fragmenteret og prekært, fordi man har for mange eller modstridende identiteter. I den flydende modernitet, modsat den faste, er idealet, at man ikke hænger fast i noget for længe ad gangen, og at man skal være fleksibel og åben over for forandringer samt behovet for at tilpasse sig disse.

Analysen af identitet hænger som nævnt nøje sammen med samtidens generelt flydende samfundstilstand, hvor alt fast og solidt fordufter, og hvor den tidligere kumulative og kontinuerlige oplevelse af tilværelsen er en saga blot:

I vores flydende moderne tidsalder bliver verden omkring os skåret i dårligt koordinerede fragmenter, alt imens vores individuelle liv opdeles i en række af usammenhængende episoder (Bauman 2004a:12-13). 
Identitetsspørgsmålet emmer således pr. definition af ambivalens og afføder følelser af tvetydighed og usikkerhed i såvel enkeltindividers som $i$ kollektivers eksistens, der begge kæmper om faste holdepunkter i en hastigt flydende tidsalder:

"Identitet" er en håbløst tvetydig forestilling og et tveægget sværd. Det kan være et krigsråb for enkeltindivider, eller for de fællesskaber, der ønsker at blive forestillet af dem (Bauman 2004a:76).

Bauman konstaterer, at tankegangen om identitet netop blev affødt af fællesskabets krise, og at identitet således bliver et surrogat for fortidens langvarige, faste forbindelser mellem mennesker eller en erstatning for de store, forkromede og forudgivne kollektive fællesskaber som familie, slægt, nation eller stat:

Så snart identiteten mistede sin sociale forankring, der fik den til at se ud som noget "naturlig" forudgivet og uden for forhandling, bliver "identifikation" stadig mere vigtigt for individer, der desperat søger efter et "vi", hvortil de kan ansøge om adgang (Bauman 2004a:24).

Denne sondring mellem "identitet" og "identifikation" er, uden at det bliver nævnt, efter alt at dømme noget, som Bauman har hentet inspiration til hos Michel Maffesoli (1996). Konsekvensen af denne udvikling er, at mennesker i stigende grad overlades til at "søge biografiske løsninger på systemiske modsætninger", som Bauman som et ekko af Beck bemærker, og han udtrykker på vanlig metaforisk vis det ubehagelige ved denne oplevelse:

Når de store havne er blevet nedlagt eller er berøvet de bølgebrydere, der tidligere gjorde dem så sikre, må de ulykkelige sejlere være beredte på at skabe sig eller indhegne deres egne små havne, hvor de kan ankre op og opbevare deres sørgelige og skrøbelige identiteter (Bauman 2004a: 46).

Disse "sørgelige og skrøbelige identiteter" er de overfladiske surrogater for fortidens kollektive identiteter, som mennesker nu fremviser for hinanden uden megen dybde eller indhold, eller som de forsøger at genindskrive i nye typer af fællesskaber. Derfor har nutidens individualistiske identiteter også et vist ekshibitionistisk skær over sig, der giver indtrykket af, at de ikke stikker synderligt dybt:

I vores flydende verden er det at forpligte sig på én enkelt livslang identitet ... en risikabel affære. Identiteter er noget man bærer og viser frem, ikke noget man opbevarer og gemmer på (Bauman 2004a:89). 
Således forekommer identitet at være ensbetydende med de overfladiske former for forestillede fællesskaber, som Bauman tidligere i forfatterskabet betegnede som "knagefællesskaber" eller "æstetiske fællesskaber", som mennesker kun indgår i for en kortere periode, eller "spøgelsesfællesskaber", som han nu betegner nutidens fremvoksende Internet-baserede fællesskaber. De livslange, ansigt-til-ansigt-forpligtelsers tidsalder er nu ifølge Baumans analyse definitivt forbi - på godt og ondt.

Med andre ord flyder identiteten, som alt andet i Baumans flydende modernitet, og det er en overvejende dyster analyse, som tilbydes i Identity, hvor Bauman i det mindste mellem linierne forekommer at begræde det langsigtede, faste og sikres skæbne, som blev beseglet med modernitetens metamorfose fra en fast til en flydende fase. Konsekvensen er, at

dagens respekterede autoriteter vil blive latterliggjort, affærdiget eller lagt for had i morgen, kendisser vil blive glemt, trend-sættende idoler vil blot blive husket gennem tv-quizzer, værdsatte nyskabelser vil blive efterladt på lossepladser, evige årsager vil blive skubbet til side af andre årsager, der ligeledes hævder at vare evigt ... uforgængelige kræfter vil falme og falde fra hinanden, mægtige politiske og økonomiske institutioner vil blive opslugt af andre, der er endnu mægtigere, eller blot forsvinde, de idiotsikre aktier vil vise sig at være idiotiske investeringer, lovende livslange karrierer viser sig at være blindgyder (Bauman 2004a:51).

Denne udvikling ser Bauman både skeptisk og imødekommende på; skeptisk, fordi den indikerer opløsningen af varige bånd og dybtfølte forpligtelser mellem mennesker; imødekommende, fordi den tilbyder nye muligheder for og friheder til autonomt at skabe det gode liv og den ønskede identitet uden fortidens båndlæggelser. Det er vigtigt at bemærke, at identitet hos Bauman ikke skal forveksles med "personlighed" eller andre lignende og næsten identiske betegnelser fra sociologiens teoretiske værktøjskasse. Identitet vekselvirker mellem at være noget overfladisk og noget dybtliggende, mellem at være langvarig og kortvarig, mellem at være frivillig og påtvunget etc. - det afgørende for identitetens udfoldelsesmuligheder er i sidste instans det omkringliggende samfunds tilstand, der enten sanktionerer og understøtter eller umuliggør og underminerer særlige former for identitet.

Selvom han ikke på noget tidspunkt generisk definerer identitet, så er Baumans forståelse af identitet i Identity dog i overvejende grad postmoderne, hvormed menes, at identitet ikke betragtes som en fast eller iboende kerne i det enkelte menneske. Inspireret af bl.a. Kenneth Gergens (1991) opfattelse fra The Saturated Self af nutidens identitetskrise, der er blevet kronisk, af pastiche-personligheder, multifreni og postmoderne informationsteknologiers mulighed for at manipulere med selvet, udvikler Bauman en markant postmoderne for- 
ståelse af identitet som noget manipulerbart og af mennesker som identitetsmæssige kamæleoner, der skifter kulør af egen vilje eller i forhold til omgivelsernes forandring og fordring. Identiteten af i dag, som Bauman har angivet andetsteds, er at sammenligne med palimpsest - som et stykke pergamentpapir, hvorpå den tidligere skrift er udvisket og en ny skrevet ovenpå. Identiteter, virtuelle som virkelige, modificeres, forkastes og slettes eller genanvendes på samme måde som med palimpsest-papir. I den flydende modernitet gælder det om at glemme, at aflære, at komme videre, at se fremad og aldrig bagud. Prisen herfor betales i solidaritetens og medmenneskelighedens hårde valuta.

\section{Makroanalysen i Europe - An Unfinished Adventure}

Det er dog ikke udelukkende den individuelle identitet, der optager Bauman. Dette review-essays anden bog bevæger sig derimod på et andet analytisk niveau end den første og interesserer sig for den kollektive form for identitet, der kan karakteriseres som "den europæiske identitet" eller selvforståelse. Normalt, når vi omtaler eller tænker på Europa, så er det enten i geografisk forstand som et afgrænset kontinent og territorium eller som grå, bureaukratiske politisk-økonomiske institutioner som EU. Sådan er det ikke hos Bauman her er Europa et værdigrundlag, en historisk enhed formet af en særlig fælles skæbne, et uafsluttet eventyr. Baumans noget alternative begrebsliggørelse af et eventyrligt Europa eller et europæisk eventyr stammer fra Denis de Rougemonts konstatering om:

At søge Europa er at skabe det! Europa eksisterer gennem dets søgen efter det uendelige - og dette er, hvad jeg betegner som et eventyr (Bauman 2004b:1).

Europa drejer sig, som i et klassisk eventyr, om transcendens, om eksperimentering, om at udfordre grænser, om de store idealer, visioner og drømme. Bauman bemærker meget rammende, at

Europa er ikke noget, du opdager; Europa er en mission - noget, der skal skabes, konstrueres, opbygges (Bauman 2004b:2).

Europa er ikke, igen på samme måde som et eventyr, men det skabes kontinuerligt af visionære mennesker og vejledes af et sæt af, ifølge Baumans udlægning, humanistiske oplysningsværdier. Mållinien kan dog aldrig nås - det ville være ensbetydende med afslutningen på eventyret. Europæerne fremstår således som eventyrer, der i deres søgen ud over det værende og det faktisk eksisterende vedvarende opdager en ny og bedre verden hinsides de kendte grænsedragninger: 
Europæerne var eventyrerne blandt dem, der elsker fred og fordragelighed; kompulsive og utrættelige vandringsmænd blandt de undselige og stillesiddende; omflakkende og omstrejfende blandt dem, der hellere ville leve deres liv i en verden, der ender ved landsbyens yderste hegnspæl (Bauman 2004b:3).

Samtidig indikerer Bauman dermed også mellem linierne, at Europa er en utopi, noget som af stræbende og aktive mennesker kan vejlede samfundets drømme hen mod det gode live eller det fælles bedste. Dette underbygges også af den polske poet, Alexander Wats forståelse: "Europas essens er tilbøjelig til at løbe forud for "det virkeligt eksisterende Europa"“ (Bauman 2004b:5). Europa som transcendens, som utopi og som eventyr gav også Europa mod på og selvtillid til at gøre en forskel i verden og forsøge at eksportere sin egen overlegenhed til andre dele af kloden:

Europa er fødestedet for en overskridende civilisation ... Europa var stedet for den eneste entitet, der udover at være en civilisation også betegnede sig selv "civilisation" og betragtede sig selv som en civilisation (Bauman 2004b:7).

Denne indledende utilslørede hyldest til drømmenes Europa får dog en forholdsvis brat afslutning, når det virkeligt eksisterende Europa i nutidens flydende modernitet efterfølgende skildres. Baumans indledende beskrivelse er forbeholdt gårsdagens Europa; nutidens Europa er derimod en ganske anden og betydeligt mere sørgelig sag.

Problemet for nutidens Europe består i den transformation af Europa fra storhed og visionær drivkraft til afmagt og forfald, som Bauman beskriver i bogens næstkommende sektioner. Dette er en tilsvarende transformation, som ovenfor blev skildret som fra en fast til en flydende modernitet. I dag er Europas vilde drømme, forkromede idealer og eventyrlige visioner under angreb fra alle sider, og Europa ser nærmest passivt og defaitistisk til. Dette beskriver Bauman i form af en overgang fra "socialstaten" til "sikkerhedsstaten", fra en interesse $i$ at forløse befolkningen fra fattigdom til at beskytte den mod indre og ydre fjender, fra velfærdssamfund til et frygtsamfund præget af kampen mod terror og for opretholdelsen af lov og orden, fra oplysning til obskurantisme, fra kollektiv forsikring mod umenneskelige levevilkår til privatiseringen og kriminaliseringen af sociale problemer; kort sagt fra europæisering til amerikanisering. I dag eksisterer Europa således i skyggen af den eneste tilbageværende supermagt eller det eneste imperium i verden, USA. Baumans ordvalg "imperium" vidner her om hans nærlæsning af Negri-Hardt-tesen, om end den ikke omtales eksplicit. Denne nye imperialisme indvarsler en ulykkelig situation, hvilket Bauman bruger meget plads på at beskrive. Det er hans 
opfattelse, at Europas værdigrundlag er mere humanistisk og oplysningspræget end det amerikanske, der forekommer kommercielt, krigerisk og egoistisk, og i den forbindelse omtaler Bauman særligt den skandinaviske ånd som efterstræbelsesværdig (Bauman 2004b:99). USA optræder, som Bauman indikerer, som en elefant i en porcelænsbutik, der knuser alt på sin kluntede vej, og han eksemplificerer dette med at konstatere, at krigen mod terrorisme i sidste instans ender med at skabe mere ødelæggelse og lemlæstelse, end den forhindrer, og at USA's aggressive politik, indenrigs som udenrigs, har umenneskelige og anti-demokratiske konsekvenser. Resultatet er, at et deciviliseret "senbarbari“, som Norbert Elias betegnede det, i disse år afløser den europæiske civilisations- og oplysningsånd. På denne måde rummer bogen en del pointer, som også kan genfindes i Jeremy Rifkins (2004) nye The European Dream, der netop også omhandler modsætningen mellem den amerikanske og den europæiske drøm. Men Rifkins analyse adskiller sig fra Baumans ved at hævde, at hvor den førstnævnte amerikanske drøm, ifølge Rifkin, er ved at tabe pusten, fordi idealerne om uindskrænket økonomisk vækst, personlig velstand og individuel egeninteresse begynder at krakelere i kanterne og efterhånden forekommer udhulede, så er den sidstnævnte europæiske radikale og humanistiske drøm derimod i fuld fart frem med sine værdier om bæredygtig udvikling, solidaritet og en nænsom værnen om fællesskabet. Helt så optimistisk er Bauman dog ikke i Europe.

Selvom bogen fremstår som en utilsløret hyldest (og lige så utilsløret opfordring) til Europa, så er der også kritiske anmærkninger og betragtninger om Europas kolonialistiske og imperialistiske fortid, om eurocentrisme, om totalitære regimer i Europas hjerte, om skabelsen af et ekskluderende Fort Europa mv. Men Bauman er i overvejende grad positiv angående den mission eller det eventyr, som Europa i sin tid påbegyndte, og som kun Europa kan afslutte, hvis det skal være en happy ending - et eventyr, der tidligere udmøntede sig i skabelsen af nationalstaten, retsstaten og velfærdsstaten og i betoningen af den universalistiske inklusionstankegang om "menneskeheden". Konsekvensen af en monopolær, imperialistisk verdensuorden styret af USA uden Europas aktive indsats kan meget vel vise sig at blive fatal:

Det er et sørgeligt øjeblik for menneskeheden, når evnen til at handle refleksivt og viljen til at handle etisk opsplittes mellem forskellige fraktioner ... Etisk oplyst global handlen, der er rettet mod at forsvare mennesker overalt imod uværdighed og mod at afhjælpe den voksende ulighed i menneskers livschancer og det stigende omfang af social uretfærdighed og menneskelig ydmygelse, udgør det mest grundlæggende vilkår for fælles overlevelse i ordets mangfoldige afskygninger (Bauman 2004b:70). 
Europa, i Baumans opfattelse, skal derfor ikke blot tage til takke med at spille andenviolin, at være introvert europæisk, begrænset til Europa og stå i skyggen af USA. Som fordums Europa skal det atter fremdyrke en "globaliserende mission", der kan erstatte det nuværende globale grænselands hobbesianske naturtilstand med en civiliseret kantiansk vision om den evige fred. For nuværende ser det dog sort ud for Europa, og som Bauman bemærker ikke blot i fysisk, men også i overført forstand: "Europa bliver gråhåret i en verden, der bliver yngre år for år" (Bauman 2004b:16). Dette minder om, hvad Agnes Heller og Ferenc Fehér i deres The Postmodern Political Condition for år tilbage humoristisk men rammende betegnede som "museificeringen af Europa", hvormed de henviste til den "proces hvorved "Europa" gradvist er ved at udvikle sig til et museum ... Europæiske nationer fokuserer på at bevare fortiden og kultivere traditionen. Gamle byer genopbygges, gamle slotte restaureres, ældgamle genstande udstilles og gamle bøger genudgives - europæerne lister rundt $\mathrm{i}$ deres byer som var de museer, fordi de er museer" (Heller \& Fehér 1988:2, 155). Bauman selv konstaterer videre i forskellige passager, at årsagen til Europas forfald og forældelse skal søges i den kendsgerning, at Europa ikke længere er eventyrlystent:

Europa er ophørt med at fremstå som et attraktivt forbillede for andre indbyggere på vores fælles planet ... De europæiske regeringer har mistet deres visioner ... Europa som helhed har mistet sin drivkraft og sin lyst til eventyr ... Europa er indadvendt. For de fleste europæiske globetrottere er resten af verden ikke længere en mission; den er nu et turistmål (Bauman 2004b:23-26).

I dag imiterer alverdens lande ikke længere Europa, men USA, og konsekvensen er en kapitalistisk alles kamp mod alle, en krigerisk og militaristisk atmosfære samt den med Jürgen Habermas' ord konstante Standortkonkurrenz mellem nationale regeringer.

Heroverfor understreger det europæiske fællesskabs slogan om "Fællesskab i forskellighed" nødvendigheden af at respektere forskellighed og dyrke fællesskabet trods forskellighederne. De klassisk europæiske oplysningsidealer om frihed, lighed og broderskab skal stå deres test over for ufrihed, ulighed og egennytte, som promoveres af det nuværende amerikanske verdenshegemoni. Vi har med Baumans indtrængende appel kort sagt brug for Europa:

Aldrig før har Europa haft behov for at være så eventyrlystent som nu. Og aldrig før har denne planet, som millioner af privilegerede og velhavende europæere deler med de fattige og underprivilegerede milliarder, behøvet et eventyrlystent Europa, som den gør det nu (Bauman 2004b:34). 
Han fortsætter med en opfordring: “Europa opfandt nationerne. Nu består opgaven $\mathrm{i}$ at opfinde menneskeheden" (Bauman 2004b:38). Vi skal derfor skabe et pax europeana, hvor de europæiske værdier og idealer atter bliver vejledende for verdens gang. Det tilsyneladende paradoksale i Baumans budskab består hermed $i$, at globaliseringen (af europæiske værdier) betragtes som løsningen på problemerne, samtidig med at globaliseringen (af amerikanske værdier) skaber umenneskelig lidelse, overflødige mennesker, krige, uretfærdighed etc. Globalisering er således såvel årsag til som løsning på problemerne. I Baumans analyse findes der ingen lokale løsninger på globale problemer, men samtidig er det de (lokale, men samtidig universalistiske) europæiske værdier og visioner, der skal lede verden på rette vej:

Nogen må våge i verdens nat, nogen må tro i mørket, nogen må være de svages bror ... nogen må bære en andens nød, nogen må vise mildhed, nogen må kæmpe for andres ret,

som den velkendte ordlyd i salme nr. 366 i Den danske Salmebog angiver. Den omtalte "nogen" må i Baumans sammenhæng i Europe, modsat Svein Ellingsens originaltekst, være Europa - Europa som garant for humanistiske værdier, holistisk tænkning og som bolværk mod uretfærdighed og en uregerlig kurs mod undergangen.

Europe - An Unfinished Adventure, hvor titlen måske ikke utilsigtet giver associationer i retning af Habermas' konstatering om den "ufuldendte modernitet", tilbyder en interessant og original sociologisk analyse af Europa, der ellers ofte kun undersøges af økonomer, politologer, jurister eller historikere. Det er ganske vist en noget polemisk, sort-hvid analyse, som præsenteres i bogen, men samtidig også en tankevækkende diagnose over verdens tilstand $\mathrm{i}$ starten af det 21. århundrede, hvor en global hobbesiansk alle-kamp-mod-alle truer med at ødelægge mulighederne for fredelig demokratisk sameksistens, menneskelig solidaritet, rationalitet og retfærdighed.

\section{En moralsk Bauman mellem mikro og makro}

Vi har kort sagt brug for Europa, som Tzvetan Todorov også noterer sig mod bogens afslutning, fordi Europa repræsenterer en særlig efterstræbelsesværdig type af identitet (Bauman 2004b:124). Dette er Bauman enig i, og hermed er ringen sluttet - fra Identity til Europe, fra mikroanalysen til makroniveauet, fra den individualiserede flydende modernitet til behovet for en revitalisering af en kollektiv europæisk ånd, der på visionær vis kan vise vejen for verdenssamfundet. På den ene side viser Bauman således enten implicit eller eksplicit i Identity og Europe konsekvenserne af de kollapsende nationale fællesskaber, den markedsdrevne globale forbrugerismes ulyksaligheder og fundamentalismens nye vækstbetingelser i forhold til at fylde det efterladte identitetstomrum 
ud. På den anden side tilbyder han samtidig en øredøvende kritik af den ensidige valorisering af individualisering og amerikanisering. Bauman viser derimod individualiseringens dialektik, at individualitet både medfører autonomi, forskellighed og frihed, men også ny kontrolformer, ensretning og en askegrå konformitet. Det samme gør globaliseringen:

Millioner og hundrede af millioner af mennesker betragter og beundrer de samme filmstjerner eller popstjerner, skifter samtidig fra heavy-metal til rap, fra bukser med svaj til seneste mode i træningstøj, raser mod den samme (globale) offentlige fjende, frygter den samme (globale) skurk og hylder den samme (globale) frelser (Bauman 2004a:97).

Det tilsyneladende unikke opløses i en endeløs forførelse af de samme forbrugsvarer og en forblændet efterabelse af de samme kendte eksempler fra de kendtes verden på det gode liv. Mennesker er dermed ikke bare cultural dopes, men også consumption dopes, der ukritisk konsumerer alt det, moden eller dens eksponenter og eksperter dikterer. Individualiseringen og globaliseringen har således også sine patologiske konsekvenser - at mennesker ikke opnår reel autonomi, men blot undertvinges nye og mere subtile former for heteronomi og repressiv forførelse, at de mangler det holistiske perspektiv, og at de ikke evner at leve sig ind i andres - og særligt samfundets svagestes - livssituation. En relateret negativ konsekvens er derfor den egocentrisme, der følger i kølvandet på selvidentitetsdyrkelsen. Ensidig fokusering på individualitet og identitet er ofte ekskluderende og kan enten føre til selvdyrkelse eller til nye og mere befæstede former for fællesskab, hvor fremmede, afvigende eller marginaliserede ikke tillades adgang og til tider helt holdes uden for det moralske fællesskab, der i nutidens flydende modernitet ofte med slet skjult ironi, sarkasme eller sentimental og nostalgisk sindelag kaldes "menneskeheden".

Hvor Identity således primært beskriver mikro-niveauet og den personlige følelse og oplevelse af på godt og ondt at leve i den flydende modernitets malstrøm, så betoner Europe derimod snarer det makro-politiske plan og amerikaniseringstendensens bieffekter. Fælles for begge bøgerne er dog, at de forholder sig til den vedvarende vekselvirkning, der finder sted mellem mikro og makro, individualisering og globalisering, og dermed transcenderer de denne klassiske dikotomi i den ånd, Mills ovenfor karakteriserede som "sociologisk fantasi“. Det er dermed kendetegnende for Baumans bøger, at mikro og makro hænger sammen, som når han analyserer de verdensomspændende og globale kræfters ubønhørlige menneskelige konsekvenser, eller når han sammenkæder globalisering med lokalisering. Selvom Bauman, som flere kommentatorer har bemærket, har tilbøjeligheder i strukturalistisk retning, hvor de sociale strukturer er determinerende for menneskelige relationer, så overser han dog aldrig den modsatrettede vekselvirkningsdynamik, hvorved selv de mindste moralske menneskelige handlinger kan afføde konsekvenser, der er mere omsiggri- 
bende end ofte antaget. Fælles for bøgerne er også deres vekselvirkning mellem afgrundsdyb pessimisme og kimen til optimisme. Det er den bastante konstatering af, at tingene $k a n$ blive bedre, at verden kan forandres, der vedvarende gennemsyrer Baumans moralsociologiske perspektiv. Vi skal derfor søge at erstatte de ekskluderende identiteter med mere inkluderende fællesskaber:

Lige som andre postulerede identiteter kan idealet om "menneskeheden" som en identitet, der favner alle andre identiteter, i sidste instans kun bero på dens postulerede tilhængeres dedikation. Ved siden af sine mindre inklusive konkurrenter forekommer "menneskeheden" for nuværende at være hæmmet og svag snarere end privilegeret og stærk. Modsat mange andre konkurrerende identiteter mangler den magtfulde redskaber - politiske institutioner, juridiske kodekser, retssale, politistyrker - der kunne indgyde mod til de sagtmodige, beslutsomhed til de tøvende og solidaritet i forhold til opnåelsen af dens omvendelsesmissioner (Bauman 2004a:79-80).

Vi har kort sagt behov for en genmoralisering af samfundslivet, hvor retfærdighed, solidaritet og ansvar for andre er i højsædet, og som Bauman engang tidligere har defineret mikro-moral, ligeledes definerer han nu makro-retfærdighed på følgende måde:

Det nærmeste man kommer på en definition på "det retfærdige samfund" er ved at hævde, at et samfund er "retfærdigt", når det ikke anser sig selv for at være retfærdigt nok og derfor er fast besluttet på at forsøge mere ihærdigt (Bauman 2004b:127).

Disse værdier - moral, solidaritet og retfærdighed - har vejledt Baumans forfatterskab lige siden de tidlige år i Polen (jf. Tester \& Jacobsen 2005), og de er stadig, og måske mere end nogensinde, til stede i Identity og Europe. Bauman forekommer visse steder overraskende nostalgisk, men det er ikke en traditionel bagudstræberisk nostalgi (jf. Davis 1979), der sigter mod fortiden, men snarere en aktivistisk nostalgi, der har et forandrende og visionært sigte med henblik på nutiden og fremtiden. Det primære problem, den dystre diagnoses årsag, som lanceres i begge bøger kan sammenkoges til følgende konstatering:

Blandt mennesker, der lever fra ét projekt til det næste, mennesker hvis livsprocesser er skåret i småstykker til kortvarige projekter, er der ingen tid til, at en diffus misfornøjelse kan kondenseres til et bud på en bedre verden ... Den slags mennesker ønsker en anderledes nutid for hver især snarere end at tænke alvorligt over en bedre fremtid for alle. Midt iblandt den daglige kamp for at holde sig oven vande er der hverken tid til eller rum for visionen om "det gode samfund" (Bauman 2004a:35). 
Det er tabet af visionen eller utopien om det fælles bedste og det gode samfund, der begrædes i begge bøgerne. Bauman lægger sig således tæt op af det forholdsvis dystre diagnostiske spor i sociologien, som med Michel Foucaults (1984:42) ord kan betegnes som en "permanent kritik af vores historiske samtid“. Dette dystre spor ender dog ikke nødvendigvis i menneskelig lidelse, nederlag og ulykke, og der er altid et lys for enden af tunnellen hos Bauman. Han afslutter derfor lidt optimistisk sin bog om Europa som verdensomspændende primus motor med de velvalgte ord fra Franz Kafkas essay Advocates:

Hvis du ikke finder noget i korridorerne, så åbn dørene; hvis du ikke finder noget bag disse døre, så findes der flere etager, og hvis du ikke finder noget deroppe, fortvivl ikke, men spring et par trappeafsatser op. Så længe du ikke stopper med at kravle, hører trapperne ikke op, og de vil blive ved med at vokse sig opad under dine klatrende fødder.

Der er meget mere end blot sociologisk indsigt og substans at hente i disse linier; der er også menneskeindsigt, og sociologi uden en sådan er efter min mening hverken meningsfuld at bedrive eller brugbar på længere sigt. Det drejer sig om at tro på den mission og det løfte, som vejledte sociologien i dens vorden, men som den ifølge både Mills og Bauman siden hen atter har glemt. De to omtalte bøger viser en Bauman, der dog stadig er overbevist om, at sociologien kan og bør gøre en forskel i verden.

Summa summarum: Er der noget nyt under den sociologiske sol i Baumans to seneste bøger? På overfladen forekommer de måske at gentage en del af hans forudgående udsagn og analyser, særligt i Identity, der samler op på tidligere mere sporadiske arbejder. Der er dog også noget nyt og vigtigt, der begrunder, at Bauman stadig har no-get på hjerte, hvilket gør ham til en uundværlig bestanddel af sociologien også i det 21. århundrede. Måske mere end nogensinde.

\section{Litteratur}

Carleheden, Mikael 2006: “Den demokratiske illusions kollaps? - om Zygmunt Baumans politiske sociologi“. I: Jacobsen, Michael Hviid \& Poul Poder (red.): Baumans udfordringer - Bjergtinder og understrømme. København: Hans Reitzels Forlag [under udgivelse].

Davis, Fred 1979: Yearning for Yesterday: A Sociology of Nostalgia. New York: Free Press.

Foucault, Michel 1984: “What Is Enlightenment?". I: Rabinow, Paul (red.): The Foucault Reader. New York: Pantheon.

Gergen, Kenneth 1991: The Saturated Self: Dilemmas of Identity in Contemporary Life. New York: Basic Books.

Heller, Agnes \& Ferenc Fehér 1988: The Postmodern Political Condition. Cambridge: Polity Press. 
Jacobsen, Michael Hviid 2004: Zygmunt Bauman - den postmoderne dialektik. København: Hans Reitzels Forlag.

Maffesoli, Michel 1996: Time of the Tribes: The Decline of Individualism in Mass Society. London: Sage Publications.

Mills, Charles Wright 1959/2002: Den sociologiske fantasi. København: Hans Reitzels Forlag.

Rifkin, Jeremy 2004: The European Dream: How Europe's Vision of the Future Is Quietly Eclipsing the American Dream. Cambridge: Polity Press.

Tester, Keith \& Michael Hviid Jacobsen 2005: Bauman Before Postmodernity - Invitation, Conversations and Annotated Bibliography, 1953-1989. Aalborg: Aalborg Universitetsforlag.

Michael Hviid Jacobsen

E-mail: mhj@socsci.auc.dk 